\title{
The Effectiveness of Community Education Services in Influencing Socio-Economic Issues in the Gravelotte Community
}

\author{
M. V. Rabapane \\ N. Wadesango \\ University of Limpopo, \\ Polokwane, South Africa
}

DOI: https://doi.org/10.36941/jesr-2020-0128

\section{Abstract}

The successes of educational services in influencing socio-economic issues in societies across the globe are captured through empirical studies. A qualitative interpretive approach was employed to investigate the effectiveness of community education in influencing socio-economic issues in the Gravelotte community. The researchers used three methods to collect data which were in-depth individual interviews, document analysis and participant observation. Ten participants were interviewed individually using open-ended interview guides. The study was conducted in the small semi-urban area of Gravelotte community in Ba-Phalaborwa municipality with a population of about 500 residents of mixed races. The collected data was thematically analysed. The findings of the study are that there is no secondary school in the Gravelotte community which is detrimental for socio-economic development in the area. The study recommends that one primary school in the area be empowered to proceed to be a secondary school or provide education up to grade 9, private companies and individuals with interest in education should be coerced support community education and that the TVET College establish a forum locally to provide marketing and interactive collaboration with locals to recruit learners who may drop out of mainstream education.

Keywords: Community education, effectiveness, socio-economic issues, participation, programmes

\section{Background of the Study}

"Education is a fundamental human right, a precious public good and an indispensable tool in building peaceful, sustainable and fairer societies" (UNESCO, 2019:34). Several studies have found important social and community benefits of learning. "The benefits are in the form of gains in social capital, improved social cohesion and integration, increased democratic participation and community involvement, or lowering the risk of crime, including reducing reoffending rates" (Schuller, 2017:45). Focusing on educating girls and women is one of the most efficient ways to combat poverty and improve economic growth in developing countries (Ostby, Urdal \& Rudolfsen, 2016). "Gender equality is also an important dimension and goal in the 2030 Agenda. Providing educational opportunities for women is therefore both a prerequisite and a driver for successful development" (UIL, 2016:43). According to recent figures, "the gap between girls and boys globally is down to $1 \%$ in primary and secondary education. However, the majority (57\%) of illiterate youth globally are still female" (UIS, 2017:76). "Discrimination against girls and women in education is more due to the unwillingness of 
public authorities to act and less a consequence of capacity, for example, bureaucratic quality and financial resources" (Ostby, Urdal \& Rudolfsen, 2016:45).

Heick (2016:76) established that "education begs for innovation and, arguments against it often turn to tempting straw man attacks". Miley et al. (2001) describe community education as a function of social work. One important feature of community education is that it operates outside the formal system of education. Community education is regarded in the Green Paper on Adult Education i.e. (Ireland) as the approach which integrates phenomenon and is not just the provision (AONTAS, 2003). Lolwana (2009) argues that the basic philosophy underlying community education is to enable and encourage the community to participate as fully as possible in education in its widest sense.

The South African community education planners intended three years ago to expand and improve programmes in the system, to ensure better articulation within the community education system, and more likelihood of meeting needs of employers and learners (DHET, 2013). Interestingly, "recent research on the effects of training seems to suggest that as well as the economic benefits, participating in vocational training also tends to increase participation in civic, political and cultural activities" (Ruhose, Thomsen \& Weilage, 2018:65).

The fundamental governing principle for a community education system must be to enable access to educational and training opportunities, and further to the level of basic education achieved by any school-leaver irrespective of race, gender, or social and economic circumstances (HESA, 2011). Community education should be accessible to all. The National Policy on Community Colleges (DHET, 2014; 2015) states that Community Colleges as community education programmes must be flexible in the programmes they offer, which should cater for the wide range of needs of adult learners and be driven by priorities of the communities they serve. Boeren (2016:76) and Desjardins (2017:43) established that "countries that have continually been found to have high participation rates in ALE, such as the Nordic countries and the Netherlands, have certain characteristics in common. Among these are a well-developed and flexible ALE system, active labour market policies and comparatively low general inequalities".

According to Baatjes \& Baatjes (2011:54), "South Africa has a long history and tradition of adult and community education outside of formal schooling. From the 1920 socialist organisations taught reading, writing and arithmetic as well as political education. In the 1940s, there was a growth in 'Night Schools' for adults in South Africa." The National Party began to rule South Africa in 1948 and imposed apartheid education principles, where teaching black people in other than registered schools became a crime. By the early 196os, nearly all-night schools had been closed (Baatjes \& Baatjes, 2011). The participants in community education are from different backgrounds with varied experiences. Omolewa (2000:54) posits that "continuing education is re-education, training and retraining opportunities that are made available to out-of-school youth and adults, employed and unemployed, to enable them to cope with new challenges of life". Data on education indicates that $8.9 \%$ of people in Ba-Phalaborwa municipality where Gravelotte is found have no schooling at all (Community Survey, 2016). The Gravelotte community has racial differences fuelled by the previous apartheid government, which separated whites from blacks. This was officially overturned in 1994 through the democratic elections. Community Education has been identified as key in the improvement of individual lives and society. Hence the research sought to verify the statement by answering the research question as outlined in the next line.

\section{Research Question}

The main research question for this study was "to what extent does community education addresses the socio-economic issues in the Gravelotte community?"

\section{Research Problem}

Gravelotte community situated in Ba-Phalaborwa Municipality of the Limpopo Province consists of a 
small town and several households within its vicinity. There is a community library that is not being used adequately. In the nearest primary school, there is an ABET centre which gives learning for levels 1 to 4 of South African Qualification Standards, but only a few people register in this centre. According to the centre manager, only a few level 4 adult learners enrol for studies each year since its inception in 2011. The community does not have a secondary school, but learners still travel by bus to do their secondary education in nearby villages about $50 \mathrm{~km}$ away. Some of the learners that pass grade 12 do not continue with their studies. In the years 2012 and 2013, learners passed grade 12 and most of them remained in the community without progressive movement towards achieving higher education qualifications. This contrasts with the report according to the community survey (2016:23) which established that "across population groups, there was an increase of persons attending at an educational institution from 1996 to 2016. The number of black Africans attending an educational institution increased from 10, 5 million in 1996 to 14, 8 million in 2016". "The Indian/Asian population had the lowest increase from 300775 in 1996 to 323986 in 2016. The number of white persons attending an education institution decreased from 980474 in 2011 to 965374 in 2016" (Community Survey, 2016:78). The people in Gravelotte are not making enough effort to use the opportunities which are given to all communities in South Africa. There is a challenge within this community which required a study to be conducted to investigate the effectiveness of community education in influencing socioeconomic issues.

\section{Theoretical Framework}

\subsection{Human Capital Theory (HCT)}

"Human Capital Theory (HCT) is one of the most used economic frameworks in educational research and policymaking" (Netcoh, 2016:67). This study is anchored on the Human Capital Theory. This theory explains that investment in education increases one's efficiency and access to the labour market. According to Reynolds \& Weagley (2003) cited by Tawiah (2017), "Human Capital is defined as an individual's knowledge, skills, and productive abilities". Studies done by Psacharopoulos (1985) and Tawiah (2017) reveal that investment in education has led to increased productivity and this has brought about economic growth. The theory also focused on capacity building premised on the perception that there is always an economic return on investment in education. In this case, there is a skill or capacity building for individual learners. "Such an investment seemed to provide returns in the form of individual skills acquisition, benefits of literacy programmes and its application for economic success and accomplishment" (Akintayo \& Oghenekohwo, 2004:87) as cited by (Tawiah, 2017).

\section{Research Methodology}

According to Flyvbjerg (2011: 302), "case study research as a strategy for methodological exploration, has been around as long as recorded history". The study used a case study method. A qualitative approach to the study was adopted with the view that an Interpretive or constructivist model is relevant in social research. Researchers share the sentiments that "the Interpretive/constructivist paradigm predominantly uses qualitative methods" (Silverman, 2000:89; Thomas, 2003; Willis, 2007; Nind \& Todd, 2011:65). In-depth individual interviews with 10 participants were conducted to get personal views on the subject under study. Document analysis of minutes, journals and municipal records were perused. Participant observation was done and notes taken using an observation sheet. "Qualitative research places emphasis upon exploring and understanding the meaning individuals or groups ascribe to a social or human problem (Creswell, 2014:102; Helm, 2000:56). This stance is supported by Denzin \& Lincoln $(2003,2005)$ who described this approach "as gaining a perspective of issues from investigating them in their specific context". The participants created a dialogue with the researcher to bring meaning in pursuit of answering the research question. A Qualitative Interpretive case study design was used for this study. Thematic analysis of the collected data was done and the next paragraph 
discusses the findings of the research.

\section{Research Findings}

The participants were asked to respond to the research question, "What are the community education programmes offered in Gravelotte? The participants in this study mentioned the education programmes offered in Gravelotte community. There are two primary schools which are Leseding Primary and Gravelotte Primary. There is an ABET centre operating within Gravelotte Primary School after hours from $14 \mathrm{Hoo}$ to $16 \mathrm{H}_{3}$ o Mondays to Thursday. The programmes provided are localised and accessible as reflected in the collected data. There is anonymity on issues of the educational programmes offered in the Gravelotte community. In responding to the first research question the participants responded in this manner.

Participant $\mathrm{KP}_{3}$ :

"I know there are two primary schools namely Gravelotte Primary and Leseding Primary. I know the ABET centre exists in the community and I also know that there is a need for a secondary school in the Gravelotte community".

Participant $\mathrm{KP}_{4}$ :

"I am aware of the centres of education in the area since I am directly involved with the teachers who are members of the teacher union within those schools. The schools are Leseding Primary School and Gravelotte Primary School which hosts an ABET centre".

The minutes of the Namakgale Circuit Management team held on the $18^{\text {th }}$ November 2018 , has the following matters as discovered in the documents analysed:

The circuit manager indicated that the schools in Gravelotte community are Leseding Primary School and Gravelotte Primary School who were monitored as a cluster in the last year. He will further visit all the schools this year 2019 as he did last year in 2018.

The data collected from interviewing participants in this study point to the need for a secondary school. The minutes of the community with EXXARO mine at the Gravelotte hotel dated 22 May 2018 supports the view of the participants:

During the Community engagement in January 2018, the Gravelotte community identified that they need a secondary school.

The study discovered that learners are transported by buses to get secondary school education in other areas about 6okm away from the community. "The implications of this are insufficient sleep, which is recognised as a serious health risk by the American Medical Association and the American Academy of Sleep Medicine, who report that many young people do not get enough hours of sleep" (Owens, 2014:81). This situation put a lot of pressure on learners to wake up earlier than is expected of them. Furthermore, the study established that there is a general awareness about educational activities and programmes in Gravelotte community as evidenced in the interactions between the school community and the local community. The schools put out posters and flyers about admissions and advertised posts in the walls of local businesses. It is further supported by the statement of Participant $\mathrm{KP}_{7}$ who responded to the question by saying:

"We currently don't have a secondary school in the area, but the community has engaged us, and we are busy coordinating the documentation to erect a school together with EXARRO mine".

The provision of education is driven by policy as attested to by Rubenson \& Desjardins (2009). 
The circuit manager when asked on the knowledge of educational programmes indicated that he is fully aware of the education programmes that happen in the community of Gravelotte, "There are two primary schools which are under the department of education and I give them monitoring and support together with the ABET centre". According to data collected from all the key participants, there is consensus that in Gravelotte there is no high school which creates an imbalance for continual educational activities. Learners travel longer distances to access secondary school education which is detrimental to community development because some of them drop out of school. One of the participants in the study pointed out that:

"Our learners travel long distances to secondary schools unmonitored and this may result in misbehaviour and lead to teenage pregnancies" (Participant KP2, female).

"Students learn best when they can connect what happens in school to their cultural contexts and experiences, when their teachers are responsive to their strengths and needs, and when their environment is identity safe" (Steele \& Cohn-Vargas, 2013:68). In this case, the Gravelotte learners are exposed to a home that is far from their schools, which disconnects them leading to failure and drop out as attested by Participant KPıwho said:

"Our children do not cope and ultimately drop out of school before completing grade 12".

The implication of dropping out of school is detrimental. Lamb, Hugo \& Huo (2017:65), posit that "school dropout is associated with a lifelong reduction in earning capacity and secure employment". However, there are valuable lessons as supported by Cantor, Osher, Berg, Steyer \& Rose (2018) in their expression of how the brain and the development of bits of intelligence and capacities are malleable, and the "development of the brain is an experience-dependent process". Possibly the travelling of these learners could provoke a lot of good initiatives and survival strategies. The level of support through family structures will be required for these learners to succeed.

"The OECD highlights that education settings are places where young people develop many of the social and emotional skills needed to become resilient and thrive" (OECD, 2015:198). The lack of a secondary school in Gravelotte community denies these learners an opportunity for ownership and a space to explore their talents. The local community have engaged the department of education and the municipality to build a secondary school. When interviewed the municipal representative said:

"The community have been asking us for a secondary school and it has been a while now and we seem to be failing them in that area" (Participant $\mathrm{KP}_{2}$, Female).

The community and the department agreed to the need for building a secondary school. However, few learners in the local community are in grade 7 . There are 16 learners in grade 7 at Leseding Primary School and 31 learners at Gravelotte Primary School. The 31 learners in Gravelotte Primary are comprised of 20 learners from as far as Nkowankowa Township and Mariveni village and 11 from the local community. The 20 learners in grade 7 travel by bus to the former model $C$ primary school in Gravelotte. The learners in Leseding Primary are few to constitute a reasonable number to start a secondary school without these travelling learners and these may be the reasons for the delay. The next finding is mentioned below.

The second sub-research question was "How successful are community education programmes in Gravelotte? There is consensus on the success of community education programmes in Gravelotte community. The participants have expressed success at different levels. The participant who is an adult learner expressed how the education he got gave him insight which makes him to help his children with their schoolwork. In the same light, the other participant is of the view that social impact can be seen through education in the community. The participants responded in this manner.

Participant KP9: 
"The education received in the ABET centre is relevant ... tackle issues of health and social wellbeing. We can help our children with homework and school-related projects."

\section{ParticipantKP $\mathrm{K}_{5}$}

"I discovered that there... Some of our graduates are employed in the PMC mine and others open their businesses."

According to the South African Government policy on education as expressed in the National Development Plan (NDP, 2030:23) "improved education ... will lead to higher employment and earnings, while more rapid economic growth will broaden opportunities for all and generate the resources required to improve education". The education programmes offered in the Gravelotte community is seen as a positive contributor to socio-economic development. This success happens amidst a low number of recorded uses of the municipal library. Perhaps the reason is because the population at Gravelotte is low compared to other areas of Ba-Phalaborwa municipality. The use of the library every month is at 600 as compared to 2500 in other areas (Ba-Phalaborwa Municipality, Report on Education: 2019-2020).

According to the findings of a study by CDE (2013:78), "the severe inequalities of educational outcomes in South Africa can be seen along with several correlated dimensions, most notably; wealth, school location, language and province". Hence one of the participants in the study expressed a different view saying:

\section{"There is no community need to be addressed through education in the area due to divisive attention to individual needs. There is no unity in the community which makes no success of educational programmes" (Participant KPı, Male)}

The other participants' views are echoed by the mine manager who emphasised that they are gaining a lot from the workers who go through skills development. The mine manager interviewed in this study, said that those who are trained are more productive and their safety skills are increased which leads to more profitable practices. The Mopani South East college representative indicated that the learners who go through their training are better off compared to those who do not get formal skills. The graduates can formalise their businesses and others get formal employment.

It is never easy to measure success in education as the benefits come after a lengthy period. However, "there has been a preference to study the economic benefits of learning. This can be attributed to the fact that the economic benefits of learning can be relatively easy to measure" (GalvidoReuda \& Vignoles, 2004:98; Feinstein \& Sabates, 2008:45). The quality of education provided has the long-lasting ability to create zeal in a child until they finish higher education after which the benefit can be measured as attested to by the participants in this study, "Most of the learners can complete grade 12 after doing primary education in Gravelotte Primary"(Participant KP1 E Participant KP8).

Schuller (2004) is of the view that "most of the education research is input or process-focused, at the expense of an equal consideration for the outcomes of learning. This lack of theoretical and substantive guidance is compounded by the fact that creating or defining a benefit is an incredibly arbitrary task. What counts as a benefit to one person might not register as a benefit for others" (Schuller, 2004:65)? Since "economic benefits can be observed through a variety of indicators such as employability, income levels and occupation” (Carnoy, 2000;43; Blondard et al., 2002), Gravelotte community still lacks in providing proper feedback on this investment since one participant mentioned that,

"The learners that stay in Gravelotte relocate to other areas due to lack of facilities in the area. Their success may be noted and credited to other areas" (Participant KP2).

The advantage of education in creating a benefit "of an increased probability of re-entering the 
labour market after periods of unemployment" (Feinstein \& Hammond, 2004:85) can also be attested to as one observes the community who most of them are unemployable after losing their jobs at the mine. In the current state the Gravelotte community is seen to access educational programmes, but on the other hand, what is being provided is not quality which might impact on success. Badat (2009;86) states that "education also has profound value for the promotion of health and wellbeing, the assertion and pursuit of social and human rights and active democratic participation".

Participants were also asked about the impact of community education as a tool for socio-economic development. There were differing opinions from the participants in the study concerning the impact of community education as a tool for socio-economic development. According to Ball (2008) and Liddy (2014:65), "when it comes to education, both defining outcomes and measuring success are difficult as the process of education is complex and multifaceted". However, comments on the impact can be made from the data collected through interviews, document analysis and observations. Participant KP1 spoke from a point of need, since there is a consensus amongst scholars that education is a prerequisite for development.

In responding to this question, the participant said:

Participant KPı:

"Wherever you go... skills are in demand for a developing community and our society is suffering because of lack of skills. Most ... lacking behind in the area of socio-economic development due to poor educational facilities and a lack of a secondary school in the area."

Ever since the ABET centre was in operation since 2010 there has been a lot of improvement in adult learners' lives. More of the adult learners were promoted at their workplaces after completing the ABET level four certificates. There is confirmation to this as said by one participant.

"Some of the mineworkers complete the ABET level 4 in Gravelotte Primary School, and we see an improvement in safety in the mine and most of them are promoted to higher positions after completing their certificates" (Participant $K P_{5}$, male).

The ABET level 4 certificates received at this centre are recognised for learnerships at the municipality and others have gone on to further their studies and their socio-economic status have improved. The participant in this study with a different view on the success of education in addressing socio-economic issues in the community is a local councillor. It could be because the participant as a local ward councillor views the services provided as inadequate in addressing socio-economic issues. The two other participants mentioned above agree with Jonck et al., (2015). There is a positive impact on society through educational programmes.

This study revealed that community education in Gravelotte community has not yet fully played a pivotal role in the advancement of the social status of individuals however there is a positive impact. The report of a study on socio-economic issues and drop out by Ansary (2017:54) asserted that "education plays an important role for the development of personality as well as to improve the quality of lifestyle and status of the individual".

The participants in this study reiterated the same sentiments when they agree on the point that an educated person or household will behave differently as opposed to families of uneducated people. The CDE (2013) postulates that "poor-quality schooling at the primary and secondary level in South Africa severely limit the youth's capacity to exploit further training opportunities". Hence there will be fewer indicatives of development if education in the primary and secondary is not qualitatively provided.

There is evidence of former learners who were at Gravelotte Primary School who among them have acquired great accolades in society. There is a former learner who is a radio personality in one of the radio stations in Limpopo. The other one is a player for the national team that won the rugby world cup in 2019. There are positive impacts out of the work in educational programmes offered in the Gravelotte community. 
However, Badat (2009:85) posits that "we are bound to protect and promote a much richer and multifaceted conception of education that views itself as also having intrinsic as well as social and political value". The Gravelotte community is void of such sustainable educational programmes due to lack of community-based educational organisations. The study revealed that there is a gap in the community which could be played by the Non-Governmental Organisations (NGOs) to support and extend the impact of community education in socio-economic development.

The socio-economic needs of the population in Gravelotte community require educational intervention. However, the current state is not enough to bring the necessary redress. Talking about development Badat (2009: 5) says "without a "thick" conception of development, it will be nighimpossible to eliminate the historical and structural economic and social legacies of apartheid, transform... and redress inequalities in patterns of wealth and ownership". Agreeably the statement speaks of how much effort should be put in addressing socio-economic issues. It emerged in the study that the current state of education input is way behind to address the gap of the past and reposition society for equality and social cohesion. Badat (2009) further states that the goals of development should be amongst others ensuring intellectual development, cultural, social and political rather than just economic.

The other research question asked was "Which factors militate against the effective implementation of community education programmes being offered in Gravelotte? Most of the participants interviewed in the study outlined several factors that militate against the implementation of community education programmes in Gravelotte community. There is consensus that the programmes are offered amid challenges. The researcher has identified three factors from the participants' responses. The first one is planning, secondly participation and thirdly lack of active partnerships.

Participant $\mathrm{KP}_{7}$ :

"Yes, the Primary school education is provided in the community but that is not enough since there is no secondary school in the area.... We are very worried about the future of our children in the Gravelotte community. We seem to be sidelined when it comes to development especially when it comes to the education of our children."

\section{Participant KP6:}

"At first, we had a high number of registered learners, but with time the numbers drop drastically. There are few students registered for the ABET level 4 class".

Participant $\mathrm{KP}_{5}$ :

"There is a conflict because even the private sector in the area like mines train their staff which could be relegated to the TVET College. There is an implementation problem around the area of skills development for employment purposes".

Although education planning for higher learning such as TVET colleges was done in collaboration with Sector Education Training Authorities SETAs as prescribed in the Skills Development Act, 1998 (Act No. 97 of 1998), there is an overlap of activities as said by Participant KP 5 :

"There is an implementation problem around the area of skills development for employment purposes".

The matter regarding educational provision extends further to the TVET College. Until the late nineteenth century higher education in the United States of America (USA) was generally dependent on the private sector (Thelin, 2011). There is a greater need for collaboration for the TVET College to fully implement the training of the labour force for the mines and other private companies in BaPhalaborwa municipality. However, there is a conflict, as indicated by the representative of the TVET College who said: 
"There is conflict because even the private sector in the area like mines, train their staff which could be relegated to the college" (Participant $\mathrm{KP}_{5}$, male).

The study established that there are trainings that are done at the Phalaborwa Mining Company (PMC) mine. These trainings could be directly handled by the college and the students could be placed for employment after graduation. The dilemma in this area is worth noting because it is not supportive of the implementation due to poor planning. The principal of the college addressed the matter of synergy in planning and reaching out to the community through consultation. The matter is still to be addressed by the planning committee to alleviate the impasse in decision making as suggested by Wadesango (2010).

Participation in educational matters is one of the factors militating against the implementation of community education in Gravelotte community. The role of stakeholders in the implementation of community education programmes as active participants is lacking. According to Participant $\mathrm{KP}_{7}$ :

"...We seem to be sidelined when it comes to development especially when it comes to the education of our children.”

The third factor that militates against the successful implementation of community education programmes is the lack of active partnerships. This study has discovered that some stakeholders are not in partnership with local educational institutions. One of the participants interviewed said:

"We do not have any partnership with the local schools, and they are not even on our agenda when we hold our meetings. We only discuss our businesses and how to grow them" (Participant KP 2, white male).

This is indicative that partnerships are a necessity if educational programmes are to be successfully implemented. Sponsorships for educational purposes are not available at the moment. The last finding is mentioned as the participants responded to the last sub research question.

In responding to the fifth research question that said "Which measures can be taken to enhance the role of community education as a tool for socio-economic development? Most participants in this study indicated their commitment to play a significant role to enhance community education as a tool for socio-economic development. NPC (2012: 38) posits that "the quality of education for blackest children is poor. This denies ... access to employment. It also reduces the earnings potential and career mobility of those who do get jobs- and limits dynamism of South African business". The researchers concur with the statement hence it is highly recommended that community education be enhanced through multiple disciplines especially for black children. Participant $\mathrm{KP}_{5}$ said:

"We see a need to create a partnership with the local primary schools to reach the community. Proper planning will enhance the implementation and success of community education programmes".

The first measure taken to enhance community education programmes is planning. The stakeholders meeting held at Mopani South East TVET college was a step in the right direction. According to the minutes of the meeting dated o7 November 2018:

It was agreed that this career guidance forum be established with delegates nominated from all the organisations and schools invited to this meeting. It is suggested that ETDP Seta be contacted to fund this initiative to train the lecturers and teachers on career guidance and work readiness programmes.

The second factor of importance to enhance the role of education is participation. The researcher observed that efforts are being made to enhance community education in Gravelotte community as reflected in the meetings and visits to the library. There is evidence as seen in the figures below of how the community engages the department and amongst themselves in anticipation of resolving the issues that hamper the success of educational programmes.

"Several empirical findings have demonstrated a positive relationship between parental 
involvement in education and academic achievement" (Tarraga et al., 2017:65). The benefits are realised in improved self-esteem of the children and their continued school attendance (Ross, 2016). According to Garbacz et al, (2017) the improvement in children's self-esteem leads to improvement in academic achievement. The third factor identified as one that could enhance the role of community education programmes in addressing socio-economic issues in Gravelotte community is partnerships. Data collected from interviews revealed that partnerships are not fully operational as mentioned by Participant $\mathrm{KP}_{5}$ who said:

"We do not have a good link with the schools in Gravelotte and I think that should change" (Participant $K P_{5}$, male).

The results of a research conducted by Mas (2014) show that community participation in education includes individual, group, and civil organisation, who partner for educational quality implementation and control. He claims that partnerships between stakeholders have a huge impact on the enhancement of education programmes. This stance is further supported by a report from the Harvard Family Research Project (2010:65) which states that "when schools and community organisations work together to support learning, everyone benefits. Furthermore, partnerships can serve to strengthen, support, and even transform individual partners, resulting in improved program quality, more efficient use of resources, and better alignment of goals and curricula".

"South Africa's rural communities should have greater opportunities to participate fully in the economic, social and political life of the country, supported by good-quality education, health care, transport and other basic services" (NDP, 2030:65). South Africa is one of the countries with the "highest unemployment rates in the world. Unemployment by the standard International Labour Organisation (ILO) definition was $27 \%$ in 2016 while the inclusion of discouraged workers raised the unemployment rate to 36\%" (Statistics South Africa, 2016:34). The study discovered that in the Gravelotte community the demand for partnerships is a relevant and much sort after intervention as supported by Participant $\mathrm{KP}_{5}$ :

"... We also see a need to create a partnership with the local primary schools to reach the community."

The efforts mentioned above are positive and can enhance community education programmes as seen worldwide. The next paragraph discusses the summary of the study.

\section{Summary}

The primary purpose of the study was to investigate the effectiveness of community education services in influencing socio-economic issues in Gravelotte community. The combination of literature study with empirical investigation using in-depth individual interviews, document analysis and participant observation for data collection allowed the researcher to reach the set objective. The findings show that there is success in other areas. However, there is a need to enhance the educational services offered in the Gravelotte community. In the literature reviewed the provision of education services is a prerogative of the government since the dawn of democracy there has been a continued commitment to make education accessible to all (NDP, 2030). Besides its provision education has been declared a societal issue, making it the responsibility of all to make it functional in addressing socio-economic issues. The study established that though criminal elements are not prevalent in the community, there is a low output in professional employment. The rate of employment for skilled personnel in the community is low. The absence of a secondary school is a course for concern. The study discovered that some attempts were made to start a secondary school, but the efforts never succeeded. Learners travel from Gravelotte to access secondary education in nearby villages. There is a disjoint amongst the stakeholders and it must be addressed. This study has given an awakening into what education in the Gravelotte community attempts to do and the shortcomings thereof. The study's important 
contribution has been to unearth the factors that are currently holding back the effectiveness of community education services in influencing socio-economic issues in the Gravelotte community.

\section{Conclusion}

Community education as a tool for socio-economic influence cannot be overemphasized. In the changing circumstances of the $21^{\text {st }}$-century education remains the core function of government in addressing the path for development and improvement of individual socio-economic status. It is, however, necessary for other role players such as business and community structures to play an active role in making the required positive contribution. Education will continue to provide the influence that brings positive socio-economic outcomes.

\section{Recommendations}

The investigation of the effectiveness of community education services in influencing socio-economic issues in Gravelotte Community has been fully concluded as a case study. The study has the following recommendations from the findings.

1. I would recommend that one primary school in the area be empowered to proceed to be a secondary school or provide education up to grade 9.

2. Private companies and business people with interest in education should be coerced to function for community education and development.

3. The TVET College can establish a forum locally to provide marketing and interactive collaboration with locals to recruit learners who may drop out of mainstream education.

\section{References}

Akintayo, M.O \& Oghenekohwo J. (2004) Developing Adult Education and Community Development. Ibadan: Education Research and Study Group

AONTAS, (2011). The Irish Journal of Adult and Community Education, Retrieved from<http://www.aontas.com/download/pdf/adultpdf $>17$ July 2018

Ansary, R. (2017). Socio-economic Factors of Dropout Situation in Rural Primary Education: A Study of Two Villages in Rajshahi District. Social Criminal 5: 176. doi: 10.4172/2375-4435.1000176

Baatjes, B. \& Baatjes, I. (2011). Facilitating Literacy: A handbook for community-based literacy workers. Johannesburg: Centre for Education Rights and Transformation.

Ba-Phalaborwa-Municipality.(2017).IDP Document Retrieved from <http://www.phalaborwa.gov.za/docs/idp /201718FINAL.IDPEDTBYMM-FINAL-FINAL-.PDF> 12 May 2019

Boeren E. (2016) Measuring Adult Lifelong Learning Participation. In: Lifelong Learning Participation in a Changing Policy Context. Palgrave Macmillan, London.

Cantor, P., Osher, D., Berg, J., Steyer, L., \& Rose, T. (2018). Malleability, plasticity, and individuality: How children learn and develop in context. Applied Developmental Science, 1.

Creswell, J. W. (2014). Research Design: Qualitative, Quantitative and Mixed Methods Approaches (4th Ed.). London: Sage.

Connolly, B. (2003). 'Women's Community education: Listening to the Voices, in The Adult Learner, Journal of Adult and Community Education in Ireland 2003. Dublin: AONTAS.

Community Survey. (2016). Statistical release Pozo1 / Statistics South Africa: A profile of education enrolment, attainment and progression in South Africa, Pretoria, South Africa: Statistics South Africa. Retrieved From<http://www.statssa.gov.za> 23 March 2018)

Curl, H., Lesnick, A. (2017). The Sojo Journal. Beyond Fix it or leave it: Toward conflict-Centred Theories of change in Education work. Antioch University

Denzin, N.K. \& Lincoln, M. (2003). The landscape of Qualitative research $\left(2^{\text {nd }}\right.$ Ed). Thousand Oaks: Sage.

Denzin, N. \& Lincoln, Y.S. (Eds.). (2005). Introduction: The Discipline and Practice of Qualitative Research. In The Sage Handbook of Qualitative Research (3rd ed., pp. 1-32). Thousand Oaks, CA: Sage.

Department of Higher Education and Training. (2014). Policy for the National Senior Certificate for Adults: A Qualification at Level 4 on the General and Further. Pretoria: Department of Higher Education and Training. 
Department of Higher Education and Training. (2015). Statistics on Post-School Education and Training in South Africa: 2013.Pretoria: Department of Higher Education and Training.

Desjardins, R. (2017). Political economy of adult learning systems. Comparative study of strategies, policies and constraints. London: Bloomsbury

Fitzsimons, P. (2015). Human Capital Theory and Education: James Cook University

Flyvbjerg, Bent (2011). Case study. In Norman K. Denzin \& Yvonna S. Lincoln (Eds.), The Sage handbook of qualitative research (4th ed., pp.301-316). Thousand Oaks, CA: Sage.

Garbacz, S. A., Herman, K. C., Thompson, A. M., and Reinke, W. M. (2017). Family engagement in education and intervention: implementation and evaluation to maximize family, school, and student outcomes. J. Sch. Psychol. 62, 1-10. doi: 10.1016/j.jsp.2017.04.002

Hashim, H. (2018). Application of Technology in the Digital Era Education. International Journal of Research in Counseling and Education, 2, 1-5.

Heick, T. (2016). "12 Barriers to innovation in education". Teach Thought. Retrieved from<http://www.teachthought.cpm/the-future-of-learning/disruption-innovation-education/>12 June 2019

Helm, M. (200o). The Spectrum of Qualitative Research - the use of Documentary Evidence. Coventry: Coventry University Publishers.

Higher Education South Africa. (2011). Position Paper on an Expanded Post-School Education System. Pretoria: Government Printers

National Development Plan, (2030). Our Future Make it work Retrieved from<https://www.gov.za>20 March 2018

Miley, K.K., O'melia, M. \& Dubois, B. (2001). Generalist social work practice. An empowering approach. Boston: Allyn and Bacon.

Mohammad, M., Ghazali, N., \& Hashim, H. (2018). Secondary School Students' Perceptions on the Use of Google + towards Improving ESL Writing Skills. International Journal of Emerging Technologies in Learning, 13, 224238. Retrieved from <https://doi.org/10.3991/ijet.v13iog.8479>16 November 2019

Munthali, G. (2015). 'Mutharika sets five-year self-reliance deadline' The Nation 26th arch. Available from: http://mwnation.com/mutharika-sets-five-year-selfreliance-deadline/ Mustafa, K., Gill Z.A. \& Nazari, 2007

Mutia, W., Doris, P. S. S., \& Roziana, B. (2018).Technological Change and Human Capital Lead to Economic Growth? Evidence from Indonesia. In Prosiding PERKEM -13 (pp. 439-553). Bangi: Universiti Kebangsaan Malaysia.

Nind, M \& Todd, L. (2011). Prospects for educational research. International Journal of Research \& Method in Education. New Castle University

Organisation for Economic Co-operation and Development. (2014). The changing role of NGOs and civil society in financing sustainable development. In Development Co-operation Report 2014: Mobilising Resources for Sustainable Development. OECD Publishing: Paris

Omolewa, M. A. (200o). Setting the Tone of Adult and Continuing Education in Africa. In S. Ndabawa, A. Oduran, T. Afrik and S. Walters (Eds.), The state of Adult Continuing Education in Africa, 11-16, Windhoek: Department of Adult and Nonformal Education, University of Namibia.

Osher, D., Cantor, P., Berg, J., Steyer, L., \& Rose, T. (2018). Drivers of human development: How relationships and context shape learning and development. Applied Developmental Science, 1. DOI: 10.1080/ 10888691.2017.139865

Ostby, G., Urdal, H. and Rudolfsen, I. (2016). What is driving gender equality in secondary education? Evidence from 57 developing countries, 1970-2010. EducationResearchInternational, Retrieved from $<$ :http://dx.doi.org/10.1155/2016/4587194 >28August 2019

Psaltis, C., Carretero, M., \& Čehajić-Clancy, S. (2017). Conflict transformation and history teaching: Social psychological theory and its contributions. In C. Psaltis, M. Carretero, \& S. Čehajić-Clancy (Eds.), History education and conflict transformation: Social psychological theories, history teaching and reconciliation (p. 1-34). Palgrave Macmillan

Ross, T. (2016). The differential effects of parental involvement on high school completion and postsecondary attendance. Educ. Policy Anal. Arch. 24, 1-38. doi: 10.14507/epaa. v24.2030

Ruhose, J., Thomsen, S. L. and Weilage, I. (2018). The wider benefits of adult learning: Work-related training and social capital. [pdf] Bonn, Institute of Labor Economics. Retrieved from $<$ www.iza.org/publications/dp/11854/the-wider-benefits-of-adult-learning-work-related-training-andsocialcapital>28 August 2019

Schuller, T. (2017). What are the wider benefits of learning across the life course? [pdf] London, Government Office for Science. Retrieved from <https://assets.publishing.service.gov.Uk/government/uploads/system /uploads/attachmentdata/file/635837/ Skills and lifelong learning the benefits of adult learning Schuller final.pdf $>28$ August 2019

Sidorkin, A. (2007). Human Capital and the Labor of Learning: A case of mistaken identity. Educational Theory 
Silverman, D. (200o). Doing Qualitative research: A practice handbook. London: Sage

Speringer, M., Goujon, A., \& Jurasszovich, S. (2018). Inequality in Educational Development from 1900 to 2015 . In Classes from National to Global Class Formation Meaning (pp.3153). Intec Open: London

Tarraga, V., Garcia, B., and Reyes, J. (2017). Home-based family involvement and academic achievement: a case study in primary education. Educ. Stud. 44, 361-375.

Tawiah, Sampson. (2017). Exploring the Effects of Adult and Community Education and Training on Economic Development of Women, in South Africa. European Scientific Journal.

Thelin, J.R (2011). A History of American Education. JHU Press: University of Kentucky

Thomas, R.M. (2003). Blending Qualitative and Quantitative research methods in theses and dissertations. California: Corwin Press.

UIL. (2016). Third Global Report on Adult Learning and Education: The impact of adult learning and education on health and well-being; employment and the labour market; and social, civic and community life. [pdf] Hamburg, UIL. Retrieved from<: https://reliefweb.int/sites/reliefweb.int/files/resources/grale-3.pdf>28 August 2019

UNESCO, (2019). $4^{\text {th }}$ Global Report on adult learning and education. Leave no one behind: Participation Equity and Inclusion. UNESCO. Germany

Wadesango, N. (2010). The extent of teacher participation in decision making in secondary schools in Zimbabwe, School Leadership \& Management, 30:3, 265-284

Willis, J.W. (2007). Foundations of Qualitative research: Interpretive and critical approaches. London: Sage. 